\title{
Developing the English Grammar Module Based-Cooperative Learning to Teach Basic English Grammar: Focus on Students' Needs
}

\author{
Arimuliani Ahmad \\ Islamic University of Riau \\ Email: arimulianiahmad@edu.uir.ac.id
}

\begin{abstract}
Grammar is like a mother of English Language competence which affects all competences in English language proficiency such as speaking, listening, reading and writing. Even though it has been learnt for 9 years by the first semester students', grammar still becomes a big problem to be mastered. If so, the lecturer should develop epic instructional media based the students' need and interest to solve this problem. This research is a part of R \& D (research and Development) design which only focuses on students' need analysis. The participant of this research 1B (first semester students) which numbered 38 students. The students are given a questionnaire to be answered to find out the target needs which consist of students' lack, students' necessity and the students' want. This research reveals that results are 76,3\% target needs of students (lacks), 76,3\% the target needs of students (necessity) and $78,9 \%$ target needs of students (wants).
\end{abstract}

\section{Key Words: The English Grammar Module, Cooperative Learning, Basic English Grammar}

\section{INTRODUCTION}

Grammar is the basic competence that takes the big role in English Language. It affects all competences in English language proficiency such as speaking, listening, reading and writing. So, it becomes important to EFL students to learn grammar communicatively to be fluent in English as spoken and then written.

However, grammar has been taught at elementary level. It means that the first semester students of English Major of FKIP-UIR have learnt it around 9 years. They supposed to be master English for that period of learning. In spite of, there are many problems occur. One of them is the students still produce some grammatical errors which supported by some relevant studies as (Chodorow et al, 2007; Watcharapunyawong et al, Arimuliani, 2014; and Arimuliani 2017.

This module is one kind of teaching materials prepared by the lecturer and given to the students to support teaching and learning process. By using the module, the students have opportunities to learn in group. The researcher assumes that the solution for the students' problems in grammar competence is by using modules because this instructional package is not only expected to become a learning 
source for English instruction, but also hoped to build high motivation and creativity of the students and develop the quality of their studying. Besides, this module is also designed to be integrated with others skills such as speaking, reading, and writing. It is going to be set to ignore monotone activity in learning Basic English Grammar.

Some instructional materials should be created by lecturers to support their teaching and learning process such as textbook, dictate, module, handout, etc. each of them has their own characteristic. In this case, the researcher will focus on module as instructional material.

Module becomes one optional instructional material because it offers the learner to learn independently with or without tutor. Besides, Gibbs (1995: 30) defines module as a paper-based resource used to support teaching and learning which can release students from excessive note taking or supplement information which is not easily available elsewhere. For the role of educators in order to not too dominant and authoritarian in learning activities. To accommodate different levels of learners and learning speed it means that for students of high learning speed they can learn more quickly and complete the module with faster anyway, but for the slow learners they may repeat it again. The learners are able to measure their own level of mastery of the material has been learned.

Indeed, Need analysis is english spesific purposes design includes a stage in which the course developers identify what specific language and skills the groups of language students will need. The identification of language and skills is used in determining and refining the content for the English specific purposes course. It can also be used to assess students and learning at the end of the course (Basturkmen, 2010). Besides, Chambers (1990) says that "need analysis should be concerned with the establishment of communicative needs and their realizations, resulting from an analysis of the communication in the target situation as target situation analysis".

Another theory proposed by Dudley-Evans and St John (1998:125) the current concept of needs analysis are devided into eight categories:

1. First is professional information about the students. The task and activities students are/will be using English for - target situation analysis and objective needs.

2. Second is personal information about the students. The factors which may effect the way they learn such as previous learning experiences, cultural information, reason for attending the course and expectations of it, attitude to English - wants, means and subjective needs.

3. Third is English language information about the students, what the students current skills and language use are - present situation analysis - which allows us to assess.

4. Fourth is the students' lacks of comprehension. 
5. Fifth is language learning information. It is the effective ways of learning the skills and language in learning needs.

6. Sixth is professional communication information about knowledge. It explain about how language and skills are used in the target situation - linguistics analysis, discourse analysis, genre analysis.

7. Seventh, what is wanted from the course.

8. Eigth is information about how the course will run. It means analysis.

From the theories above, the reseacher do the need analysis in Second semester students of Islamic University of Riau is from DudleyEvans and St John's theory. This theory is related to the situation and the gathering of information about the needs. The writer of this study choose Hutchinson and Water (1987) framework about the kind of information that the course designers need to gather from an analysis of needs which are paired into target needs and learning needs. The first is the target needs based on Hutchinson and Water (1987) suggest that "target needs is something of an umbrella term, which in practice hides a number of important distinctions. It is more useful to look at the target situation in terms of necessities, lacks and wants".

Second, the learning needs are the information recorded in term of the circumstances to develop the language items, skills, strategies, subject knowledge. Psychological, motivation, and material are contributed to the learning needs. The needs, potential and constraints of the route (i.e. the learning situation) must also be taken into account, if we are going to have any useful analysis of learner needs (Hutchinson \& Water, 1987: 59). Helen Basturkmen (2010) says that developing the syllabus, "one of key issues in developing is the spesific course should be in terms of target audience. A distinction is drawn between courses that are 'wide angled' (designed for a more general group of students) and those that are "narrow angled' (designed for a very specific group of students)."

In addition, according to Basturkmen (2010), wide angled' are designed for classes focused on board academic skills or a register which encompasses many subfields. 'narrow angled' refers to courses that are more specific, as it has been designed for students who have largely homogenous needs and who have a particular type of academic or work environment in mind. Furthermore, courses can be even more specific.

The development of wide-angled reflects the unwillingness of universities to fund the development of highly specific narrow-angled courses. The terms 'wide and narrow-angled' course designs suggest a two way divide. However, courses can be more or less narrow or wide and can be seen as existing on a continuum of specificity. At one end of this continuum is the most general courses toward the other end of the continuum are course focusing on specific needs and language use of particular area of work or study. 
Based on the theory, the developing reading module syllabus and course are based on the specific course or narrow angled which should be implemented to students in the group. The students should get specific content related to the suitable content of its.

\section{METHOD}

This is the first stage for research and development design which is need analysis. The researcher distributed questionnaire which consist of three indicators as table 1 . The questionnaire was used to find out the current needs of First Semester Students in English Department of FKIP - UIR. This research was developed based on the students' need of studying Basic English Grammar at First Semester Students in English Department of FKIP - UIR. Besides, this questionnaire also purposes to find out the students' problem in learning Grammar.

Table 1.

Indicators of Students' Need Analysis in Learning Grammar

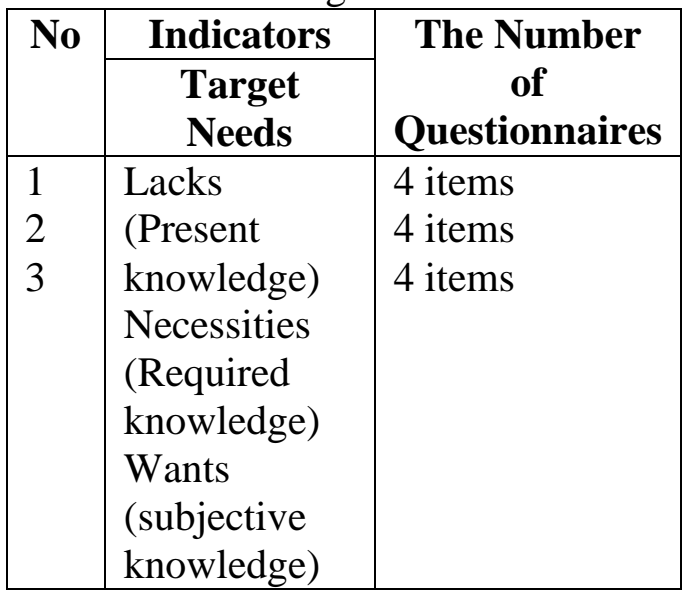

Developed from "Panduan

Pengembangan Bahan Ajar"

(Depdiknas : 2008)

The data of this need analysis were categorized into quantitative data. The questionnaire was in the form of likert scale that has four scale namely $1=$ disagree, $2=$ slightly disagree, $3=$ slightly agree, $4=$ agree .

Table 2.

Average of Questionnaire

\begin{tabular}{|l|c|l|}
\hline No & Point & Option \\
\hline 1 & 1 & Poor \\
2 & 2 & Fair \\
& 3 & Good \\
4 & 4 & Very Good \\
5 & 5 & Excellent \\
\hline \multicolumn{2}{|c|}{ Depdiknas (2008) }
\end{tabular}

1. Analyzing Need Analysis

This need analysis will be done by analyzing students' midterm test result. After getting that result, researcher will consider stakeholders' expectation and then consider that result by comparing indicators that should be achieved from syllabus.

Since the researcher start this research based on the students' need on learning material, the researcher will analyzed the data based on likert scale. Sugiyono (2009: 89) explains likert scale as the obtained data presented in tabular format in order to determine the percentage and freequency of each alternative answers and to facilitate the reading data. The result is analyzed by finding the percentage of each statement for each answer option, by using this following formula:

ELT- Lectura: Jurnal Pendidikan, Vol 5, No 2, August 2018 
Note: $\mathrm{P}=$ Percentage

(Sudjana, 2006)

$f=$ Answering frequency

$n=$ The number of respondent

The criteria of the need analysis could explain that the percentage of the number and prototype criteria were inversely. The smaller of the percentage is the higher of the demand for the item in questions, and vice versa. Therefore, it is assumed that if the number of respondents are less, the higher need of the things is needed or vise versa. To analyze the need criteria, sematic differential is used. If the result is very low, it means that the need of the product is high.

The procedure followed was done to get the criteria percentage of need analysis.

Table 3.

Percentage of Need Criteria

\begin{tabular}{|l|l|l|}
\hline No & $\begin{array}{l}\text { Percentage } \\
\text { of need } \\
\text { analysis (\%) }\end{array}$ & $\begin{array}{l}\text { Need } \\
\text { Criteria }\end{array}$ \\
\hline 1 & $0-20$ & Very high \\
\hline 2 & $21-40$ & High \\
\hline 3 & $41-60$ & Moderate \\
\hline 4 & $61-80$ & Low \\
\hline 5 & $81-100$ & Very low \\
\hline
\end{tabular}

Sudjana (2005)

\section{FINDING AND DISCUSSION The Analysis of the Questionnaire}

The analysis of the students' questionnaire helped the researcher cover to the target needs which divided into lacks, necessities and wants of the First Semester Student of FKIP-UIR and

$$
\mathrm{P}=f / n \mathrm{X} 100 \%
$$

learning needs which divided in terms of ability, learning motivation, and activeness.

Based on the analysis of student learning outcomes, the researcher obtained the information that the ability of the students can be categorized into three categories: high, medium and low and each student has different learning speeds. In classical learning systems such as read the text then identified the main idea and detail, and then answered the questions directly, need to develop an optimal capability because students who learn quickly have to wait for students who learn slowly.

The students' motivation during learning process in the reading class was low. It can be seen from the number of students who do not complete the tasks assigned by the lecturers. The students just silent and students did not actived on learning. While there were students who responded to the teacher's question to answer even though the answer was not right and many students remained silent when lecturer asked a question. Students seem to wait for information only and the response from teachers, they have not been so actively seek their own answers by reading books available actively.

The existing text books were not attractive; the material description was too long so that they become saturated, when the lecturer asked the students to open their books, the student's response so slowly. Based on analysis 
of the characteristics of students reading above the researcher developed a grammar module based Cooperative Learning. In addition, the module description presented with attractive pictures and directing students toward the concepts, the materials were building the students' knowledge. This module was given a lot of exercises that support the students to be more active for finding the answers. Finally, at the end of the learning process the students were able construct their own knowledge through active involvement in the learning process by using this module.

The tables below show the result of questionnaire to find the target needs.
Table 4

Target needs : Lacks

\begin{tabular}{|c|c|c|c|c|c|}
\hline \multirow{2}{*}{$\begin{array}{l}\mathrm{N} \\
\mathrm{O}\end{array}$} & \multirow{2}{*}{$\begin{array}{c}\text { Indicator } \\
\text { Target needs : } \\
\text { Lacks (Present } \\
\text { knowledge) }\end{array}$} & \multicolumn{4}{|c|}{ Number of Students / \% } \\
\hline & & 4 & 3 & 2 & 1 \\
\hline 1 & $\begin{array}{l}\text { The students' } \\
\text { difficulties in } \\
\text { using grammar } \\
\text { in the correct } \\
\text { context. }\end{array}$ & $\begin{array}{l}68,4 \\
(26)\end{array}$ & $\begin{array}{l}21,0 \\
(8)\end{array}$ & $\begin{array}{l}5,3 \\
(2)\end{array}$ & $\begin{array}{l}5,3 \\
(2)\end{array}$ \\
\hline 2 & $\begin{array}{l}\text { The students are } \\
\text { unmotivated by } \\
\text { using grammar } \\
\text { books. }\end{array}$ & $\begin{array}{l}76,3 \\
(29)\end{array}$ & $\begin{array}{l}13,2 \\
(5)\end{array}$ & $\begin{array}{l}7.9 \\
(3)\end{array}$ & $\begin{array}{l}2,6 \\
(1)\end{array}$ \\
\hline 3 & $\begin{array}{l}\text { The students do } \\
\text { not have the } \\
\text { material as a } \\
\text { guide } \\
\text { structure } \\
\text { assignment. }\end{array}$ & $\begin{array}{l}73,7 \\
(28)\end{array}$ & $\begin{array}{l}21,0 \\
(8)\end{array}$ & $\begin{array}{l}5,3 \\
(2)\end{array}$ & - \\
\hline 4 & $\begin{array}{l}\text { The students do } \\
\text { not have the } \\
\text { material consists } \\
\text { of explanation, } \\
\text { examples, } \\
\text { exercises and } \\
\text { test to mastering } \\
\text { the material. }\end{array}$ & $\begin{array}{l}60,5 \\
(23)\end{array}$ & $\begin{array}{l}23,7 \\
(9)\end{array}$ & $\begin{array}{c}10,5 \\
\text { (4) }\end{array}$ & $\begin{array}{l}5,3 \\
(2)\end{array}$ \\
\hline
\end{tabular}

\section{Target needs : Lacks}

Table 4 shows the calculation of item no. 1 "the students' got difficulties in using grammar in the correct context". It could be assumed that there were 26 students $(68.4 \%)$ who agreed; there were 8 students $(21.0 \%)$ slightly agreed; there were 2 students (5.3\%) who slightly disagreed; there were 2 students (5.3\%) disagreed. Based on the percentage of the data, most of the students answered agree, $68.4 \%$. It can be concluded that the students still had less difficulties in getting the meaning of what they read. 
Table 4 shows that the calculation of item no. 2 "The students are unmotivated by using grammar books" It could be assumed that there were 29 students $(76.3 \%)$ who agreed; there were 5 students $(13.2 \%)$ who slightly agreed; there were 3 students $(7,9 \%)$ who slightly disagreed; there were 1 student $(2.6 \%)$ who disagreed. Over all, most of the students $(76.3 \%)$ answered agree. It can be concluded that the students were unmotivated by using a textbooks.

Table 5.

Target Needs : Necessities

Table 4 shows the calculation of item no. 3 "The students do not have

\begin{tabular}{|c|c|c|c|c|c|}
\hline \multirow{2}{*}{$\begin{array}{l}\mathbf{N} \\
\mathbf{o}\end{array}$} & \multirow{2}{*}{$\begin{array}{c}\text { Indicator } \\
\text { Target } \\
\text { Needs : } \\
\text { Necessities } \\
\text { (Reguired } \\
\text { Knowledge) }\end{array}$} & \multicolumn{4}{|c|}{ Number of Percentage } \\
\hline & & 4 & 3 & 2 & 1 \\
\hline 1 & $\begin{array}{l}\text { The students } \\
\text { need works } \\
\text { in pair as the } \\
\text { structure } \\
\text { assignment. }\end{array}$ & $\begin{array}{l}52,6 \\
(20)\end{array}$ & $\begin{array}{l}26,3 \\
(10)\end{array}$ & $\begin{array}{c}13,2 \\
(5)\end{array}$ & $\begin{array}{l}7,9 \\
(3)\end{array}$ \\
\hline 2 & $\begin{array}{l}\text { The } \\
\text { student's } \\
\text { interest uses } \\
\text { Cooperative } \\
\text { Learning } \\
\text { activity in } \\
\text { grammar } \\
\text { learning. }\end{array}$ & $\begin{array}{l}57,9 \\
(22)\end{array}$ & $\begin{array}{l}23,7 \\
(9)\end{array}$ & $\begin{array}{c}10,5 \\
(4)\end{array}$ & $\begin{array}{l}7,9 \\
(3)\end{array}$ \\
\hline 3 & $\begin{array}{l}\text { The } \\
\text { activities } \\
\text { should be } \\
\text { suitable with } \\
\text { students' } \\
\text { competence. }\end{array}$ & $\begin{array}{l}76,3 \\
(29)\end{array}$ & $\begin{array}{l}23,7 \\
(9)\end{array}$ & - & - \\
\hline 4 & $\begin{array}{l}\text { The } \\
\text { activities do } \\
\text { at home as } \\
\text { structure }\end{array}$ & $\begin{array}{l}71,1 \\
(27)\end{array}$ & $\begin{array}{l}28,9 \\
(11)\end{array}$ & - & - \\
\hline
\end{tabular}

the material as a guide in structure assignment". It could be assumed that there were 28 students $(73,7 \%)$ who agreed; there were 8 students $(21.0 \%)$ slightly agreed; there were 2 students $(5.3 \%)$ who slightly disagreed. It can be concluded that the students need interesting material in reading, the students were motivated by using suitable materials with their level.

Table 4 shows that the calculation of item no. 4 "The students' do not have the material consists of explanation, examples, exercises and test to mastering the material". It could be assumed that there were 23 students $(60,5 \%)$ who agreed; there were 9 students $(23,7 \%)$ who slightly agree; there were 4 students $(10,5 \%)$ who slightly disagree; and there were 2 students $(5,3 \%)$ disagree. It means that the students need the material consists of explanation, examples, exercises and test in order to mastering the material. The researcher draws the conclusion that to overcome the students weaknesses in grammar to fulfill the students' need, the researcher plans to solve the students' needs by developing their grammar competence with Cooperative Learning based-module. 


\section{Target Needs : Necessities}

Table 5 shows that the result of questionnaire of target needs (Necessities). The purpose of this sections were to find out the students' neccesary in reading. The result of questionnaire showed sub indicators which needed by the students.

The researcher analyzed sub indicators to fulfill the students' data from the questionnaire in reading module. Table 13 shows the calculation of item no. 1 "The students need work in pair as the structure assignment". It could be assumed that there were 20 students $(52,6 \%)$ who agreed; there were 10 students $(26,3 \%)$ who slightly agree; there were 5 students $(13,2 \%)$ who slightly disagree; and there were 3 students $(7,9 \%)$ disagree. Based on the percentage of the data, most of students answered agree and slightly agree, it can be assumed that the result of need criteria is the students need work in pair as the structure assignment.

Table 5 shows the calculation of item no. 2 "The student's interest uses Cooperative Learning activity in reading learning". It could be assumed that there were 22 students $(57,9 \%)$ who agreed; there were 9 students $(23,7 \%)$ who slightly agree; there were 4 students $(10,5 \%)$ who slightly disagree; there were 3 students $(7,9 \%)$ disagree. It means that the most of students answered the student's interest uses Cooperative Learning activity in reading learning.

Table 5 shows the calculation of item no. 3 "The activities should be suitable with students' competence". It could be assumed that there were 29 students $(76,3 \%)$ who agreed; that there were 9 students $(23,7 \%)$ who slightly agree. It means that the most of students answered the activities should be suitable with students' competence.

Table 5 shows the calculation of item no. 4 "The activities do at home as structure assignment". It could be assumed that there were 27 students $(71,1 \%)$ who agreed; that there were 11 students $(28,9 \%)$ who slightly agree. It means that the students need the activities in reading allowed do at home as structure assignment not only in the classroom. After analyzing the necessity, the researcher concluded that the students needed the grammar exercise as structure assignment. 
Table 6

Target needs : Wants

\begin{tabular}{|c|c|c|c|c|c|}
\hline \multirow{2}{*}{$\begin{array}{l}\mathbf{N} \\
\mathbf{0}\end{array}$} & \multirow{2}{*}{$\begin{array}{c}\text { Indicator } \\
\text { Target needs : } \\
\text { Wants (Subjective } \\
\text { Knowledge) } \\
\end{array}$} & \multicolumn{4}{|c|}{ Number of Percentage } \\
\hline & & 4 & 3 & 2 & 1 \\
\hline 1 & $\begin{array}{l}\text { The processes and } \\
\text { procedure in } \\
\text { learning grammar } \\
\text { through reading } \\
\text { done by each } \\
\text { group. }\end{array}$ & $\begin{array}{l}52,6 \\
(20)\end{array}$ & $\begin{array}{l}21,1 \\
(8)\end{array}$ & $\begin{array}{c}15,8 \\
(6)\end{array}$ & $\begin{array}{c}10,5 \\
(4)\end{array}$ \\
\hline 2 & $\begin{array}{l}\text { The processes and } \\
\text { procedure in } \\
\text { learning grammar } \\
\text { through reading } \\
\text { used think pair } \\
\text { shares strategy. }\end{array}$ & $\begin{array}{l}76,3 \\
(29)\end{array}$ & $\begin{array}{l}18,4 \\
(7)\end{array}$ & $\begin{array}{l}5,3 \\
(2)\end{array}$ & - \\
\hline 3 & $\begin{array}{l}\text { The processes and } \\
\text { procedure in } \\
\text { reading by group in } \\
\text { turn. }\end{array}$ & $\begin{array}{l}78,9 \\
(30)\end{array}$ & $\begin{array}{l}21,1 \\
(8)\end{array}$ & - & - \\
\hline 4 & $\begin{array}{l}\text { The processes and } \\
\text { procedure used } \\
\text { should be recorded } \\
\text { by each group. }\end{array}$ & $\begin{array}{l}55,2 \\
(21)\end{array}$ & $\begin{array}{l}18,4 \\
(7)\end{array}$ & $\begin{array}{c}13,2 \\
(5)\end{array}$ & $\begin{array}{c}13,2 \\
(5)\end{array}$ \\
\hline
\end{tabular}

\section{Target Needs : Wants}

Table 6 shows the calculation of item no. 1 "The processes and procedure in learning grammar through reading done by each group". It could be assumed that there were 20 students $(52,6 \%)$ who agreed; there were 8 students $(21,1 \%)$ who slightly agree; there were 6 students $(15,8 \%)$ who slightly disagree; and there were 4 students $(10,5 \%)$ disagree. It means that the students wants the processes and procedures in reading done by each group.

Table 6 shows the calculation of item no. 2 "The processes and procedure in learning grammar through reading used think pair shares technique”. It could be assumed that there were 29 students $(76,3 \%)$ who agreed; there were 7 students $(18,4 \%)$ who slightly agree; there were 2 students $(5,3 \%)$ who slightly disagree. It means that the students wants the processes and procedures in reading used think pair shares technique.

Table 6 shows the calculation of item no. 3 "The processes and procedure in reading by group in turn". It could be assumed that there were 30 students $(78,9 \%)$ who agreed; there were 8 students $(21,1 \%)$ who slightly agree. It means that the students want sthe processes and procedure in reading by group in turn.

Table 6 shows the calculation of item no. 4 "The processes and procedure used should be recorded by each group". It could be assumed that there were 21 students $(55,2 \%)$ who agreed; there were 7 students $(18,4 \%)$ who slightly agree; there were 5 students $(13,2 \%)$ who slightly disagree; and there were 5 students $(13,2 \%)$ disagree. It means that the student's wants all the activities in learning grammar through reading processes and the students agree the procedures should be recorded by each group.

\section{CONCLUSION}

The analysis of current needs of second semester students of FKIP UIR was done by getting some data from needs analysis. The needs analysis was to find out the analysis of current needs of the first semester students of FKIP-UIR. The analyisis of current needs followed the procedure for gathering information about needs, the reseacher chose Hutchinson and 
Water (1987:59) about the kind of information to gather from an analysis of needs which are paired into target needs.

a. The Target Needs of Students (lacks)

The reseacher did the analysis of students by taking the data from questionnaire. The target needs divided into Lacks, Necessities, and Wants. The items of lacks result of questionnaire got the percentage $76,3 \%$. It means that the students weaknesses in basic grammar and to fulfill the students' need, the reseacher plans to solve the students' needs by developing the basic English Grammar module based cooperative learning for teaching Basic English Grammar at the first semester students of FKIP-UIR.

The research finding was supported by Hutchinson and Water (2010:40). The reseacher did the analysis of students by taking the data from questionnaire. The needs divided into lack, neccessity, and wants. The items of lack result questionnaire got the highest percentage $76,3 \%$. It means that the students weaknesses in grammar material and to fulfill the students' need, the reseacher plans to solve the students' needs by developing basic grammar material in module

b. The Target Needs of Students (necessity)

The items of necessity result of questionnaire showed the higest percentage $76,3 \%$. It means that the students need mdule to support them in their learning, therefore, the students needs are focused on grammar through reading text. The reseacher draws the conclusion that to overcome the students needs module based cooperative learning. The reseacher plans to solve the students' needs by developing grammar material together with reading text module.

c. The Target Needs of Students (wants)

The items of wants was showed the result of questionnaire showed the higest score of percentage $78,9 \%$. It means that grammar which are integrated with reading and speaking skill showed the highest percentage to be developed for the purpose of the students'academic and their purposes of future needs.

\section{REFERENCES}

Ahmad, Arimuliani. (2014). Sytactic Errors Made by the Grade XI IPA 1 Students of SMAN 1 Bangkinang in Writing Report Text. Journal of English for Academic (JSHMIC), Vol 1, No 1, July 2014.

(2017) Grammatical

Errors in Writing Paragraph by the Second Semester Students At English Study Program of FKIP-Universitas Islam Riau. International Seminar Proceeding International Seminar on Education, Language, Literature, and Art (ISELLA). 2017.

Basturkman, Helen. (2010). Developing Courses in English for Specific Purposes. London: Palgrave Macmillan. 
Chodorow, Martin. Tetreault, R. Joel and Han, Na-Rae. Detection of Grammatical Errors Involving Prepositions. Proceedings of the 4th ACL-SIGSEM Workshop on Prepositions, pages 25-30, Prague, Czech Republic, June 2007. Association for Computational Linguistics.

Dudley-Evans, T., and M. St. John. (1998). Developments in English for Spesific Purposes. New York: Cambridge University Press.

Depdiknas. 2008. Panduan Pengembangan Indikator. Jakarta: Dirjen Manajemen Dikdasmen.

Gibbs, G. 1995. Improving the Quality of Student Learning. Bristol: Oxford Centre for Staff Development.

Hutchinson \& Waters. 1987. English for Specific Purposes. New York: Cambridge University Press.

Sudjana, N. (2005). Dasar-dasar Proses Belajar Mengajar. Bandung: Sinar Baru Algensindo Offset.

Sugiyono. 2010. Metode Penelitian Pendidikan Pendekatan Kuantitatif, dan $R \& D$. Bandung: Alfabeta. 